Article

\title{
Nutritional Composition, Bioactive Compounds and Functional Evaluation of Various Parts of Cajanus cajan (L.) Millsp
}

\author{
Shu-Er Yang ${ }^{1}$, Thuy-Lan Thi Vo ${ }^{2}$, Chien-Lin Chen ${ }^{2}$, Nae-Cherng Yang ${ }^{3}{ }^{(\mathbb{D}}$, Chen-I Chen ${ }^{4}$ and \\ Tuzz-Ying Song 2,*(D) \\ 1 Department of Beauty Science and Graduate Institute of Beauty Science Technology, \\ Chienkuo Technology University, Changhua 515, Taiwan; jessica@ctu.edu.tw \\ 2 Department of Food Science and Biotechnology, Da-Yeh University, Changhua 515, Taiwan; \\ d0467601@cloud.dyu.edu.tw (T.-L.T.V.); chienlin@mail.dyu.edu.tw (C.-L.C.) \\ 3 Department of Nutrition, Chung Shan Medical University, Taichung 402, Taiwan; naeman@csmu.edu.tw \\ 4 Taitung District Agricultural Research and Extension Station, Council of Agriculture, Taitung 950, Taiwan; \\ 652@mail.ttdares.gov.tw \\ * Correspondence: song77@mail.dyu.edu.tw; Tel.: +886-4-8511-888 (ext. 2282); Fax: +886-4-8511-320
}

Received: 12 October 2020; Accepted: 12 November 2020; Published: 19 November 2020

\begin{abstract}
The pigeon pea (Cajanus cajan (L.) Millsp.) is one of the major grain legume crops of the tropical world and recent evidence indicates that it possesses various health benefits. However, to the best of our knowledge, no comparison has been made on the nutritional composition and biological functions of its leaves, seeds, and roots. Therefore, the present study investigates which part of the C. cajan (L.) Millsp plant has the highest potential for development as a health food product. Results show that C. cajan (L.) Millsp roots (CCR) have a higher total polyphenol content (TPC) and total flavonoids flavonoid (TFC) contents than leaves and seeds. The antioxidant, anti-hyperglycemic, and anti-bacterial activities of CCR extracted with hot water (HWCR), 50\% ethanol (EECR50), and 95\% ethanol (EECR95) were determined. We found that EECR95 had the strongest antioxidant activity, as evaluated by 1,1-Diphenyl-2-picrylhydrazyl radical (DPPH) and 2,2'-azino-bis (3-ethylbenzothiazoline-6-sulfonic acid) $\left(\mathrm{ABTS}^{+}\right)$scavenging, and reducing power. EECR95 exhibited higher anti-hyperglycemic ability (inhibition of $\alpha$-glucosidase and $\alpha$-amylase activities) and anti-glycation effects ( $\mathrm{IC}_{50}=39,120$ and $229 \mu \mathrm{g} / \mathrm{mL}$, respectively) than HWCR and EECR50. EECR95 also exhibited potent anti-bacterial activities on E. coli, Staphylococcus aureus, Porphyromonas gingivalis, and Streptococcus mutans, with minimum inhibitory concentrations of 113, 180,16 , and $100 \mu \mathrm{g} / \mathrm{mL}$, respectively. Based on above results, we conclude that CCR has considerable potential for health food development and further studies of CCR in animals to confirm these biological effects and safety issues are warranted.
\end{abstract}

Keywords: Cajanus cajan (L.) Millsp; nutrition; antioxidant; hypoglycemic; anti-bacterial

\section{Introduction}

Cajanus cajan (L.) Millsp, known as pigeon pea, is one of the major grain legume crops of the tropical world. Taiwanese aborigines have consumed pigeon pea since ancient times and found that the seeds, leaves, and roots of $C$. cajan have various functions, such as inhibition of swelling of internal organs, utility in healing wound and cancer therapy [1]. A large number of compounds have been isolated from C. cajan that have excellent biological activities. As a traditional folk medicine, the leaves of C. cajan have been widely used to arrest blood, relieve pain and kill worms [2]. C. cajan leaves are rich in flavonoids, stilbenes, saponin, tannin, reducing sugars, resins and terpenoids which are potentially antioxidant, 
antibacterial, hypocholesterolemic, anti-inflammatory [3]. C. cajan seeds are rich in proteins, minerals and unsaturated fatty acids and are used as food and animal fodder [4]. C. cajan seeds are also used against diabetes, fever, dysentery, hepatitis, measles and as an antimalarial remedy $[5,6]$.

C. cajan roots (CCR) contain compounds such as genistein, genistin, hexadecanoic acid, $\alpha$-amyrin, $\beta$-sitosterol, longistylin A, longistylin $C$, cajanuslactone, coumarin, cajaninstilbene, pinostrobin, vitexin, and orientin that have reported anticancer, antibacterial, and antiplasmodic activities [3,7]. Recently, we found that the antioxidant and anti-inflammation mechanisms of ethanol extracts of C. cajan root (EECR) involves the activation of nuclear factor erythroid 2-related factor 2 (Nrf-2) and peroxisome proliferator-activated receptors (PPAR- $\gamma$ )/antioxidant protein heme oxygenase-1 (HO-1) system and inhibition of nuclear factor kappa B (NF-kB) signaling pathway [8].

Although the functions and active compounds of the leaves, seeds and roots of $C$. cajan have been reported, no analytical data are available on the basic nutritional composition or the comparison of biological functions in leaves, seeds and roots of $C$. cajan. The aim of this study is to explore the nutrient composition, antioxidant capacity and functional components of the roots, leaves and seeds of C. cajan to understand which part is the most beneficial for humans. Herein, we first compared the basic nutritional composition and biological activities of leaves, seeds and roots of $C$. cajan, then we chose the most effective part of C. cajan and extracted it with hot water $\left(95 \pm 2{ }^{\circ} \mathrm{C}\right), 50 \%$ and $95 \%$ ethanol for evaluation of the antioxidant, hypoglycemic and antibacterial activities in order to provide preliminary data for the development of $C$. cajan health products in the future.

\section{Materials and Methods}

\subsection{Chemicals and Reagents}

Gallic acid, quercetin, linoleic acid, nitro blue tetrazolium (NBT), 2,2-diphenyl-â-picrylhdrazyl $(\mathrm{DPPH})$, horseradish peroxidase (HRPase), 2,2'-azinobis(3-ethylbenzothiazoline-6-sulfonate (ABTS)), ferric chloride, ferrozine (3-(2-pyridyl)-5,6-bis (4-phenylsulfonic acid)-1,2,4-triazine), sodium nitroprusside, naphthylethylenediamine dihydrochloride, potato starch, sodium acetate, sodium phosphate, sodium potassium tartrate, sodium chloride, $\alpha$-amylase from porcine pancreas (EC 3.2.1.1), $\alpha$-glucosidase from Saccharomyces cerevisiae (EC 3.2.1.20), and all other reagents were purchased from Sigma Chemical Company (St. Louis, Missouri, USA). Tween 20 (polyoxyethylenesorbitan monolaurate), ascorbic acid, Folin-Ciocalteu reagent, Griess reagent, and phenazine methosulfate (PMS) were purchased from E. Merck Co. (Darmstadt, Germany). Hydrogen peroxide, sodium dihydrogen phosphate, anhydrous dipotassium hydrogen phosphate, potassium dihydrogen phosphate, boric acid, and disodium hydrogen phosphate were purchased from Shimakyu Co. (Fukuoka, Japan). Dimethyl sulfoxide (DMSO) was obtained from Fluka Chemie (Buchs, Switzerland).

\subsection{Microorganisms and Culture Medium}

Staphylococcus aureus (BCRC 10781) and Escherichia coli (BCRC 10316) were purchased from the Food Industry Research \& Development Institute (Hsin Chu, Taiwan). They were maintained on an agar slant at $4{ }^{\circ} \mathrm{C}$. Each bacterial strain was subcultured overnight at $35^{\circ} \mathrm{C}$ in Mueller-Hilton agar slants. The bacterial growth was harvested using $5 \mathrm{~mL}$ of sterile saline water, its absorbance was adjusted at $550 \mathrm{~nm}$ and diluted to attain viable cell count of $10^{7} \mathrm{CFU} / \mathrm{mL}$ using spectrophotometer. Porphyromonas gingivalis (BCRC 14417) and Streptococcus mutans (BCRC 10793), proven cariogenic dental pathogens, were used mainly in this study for minimum inhibitory concentrations (MIC) determination. P. gingivalis were grown in ultrafiltered tryptic soy medium (TSM) (containing 5\% defibrinated sheep blood) incubated in the anaerobic jar and the jar was kept in the incubator for $48 \mathrm{~h}$. S. mutans were incubated in brain heart infusion (DIFCO 0418; Becton, Dickinson and Company, Sparks, Maryland, USA) broth at $37^{\circ} \mathrm{C}$ with shaking at $200 \mathrm{rpm}$. 


\subsection{Preparation of Hot Water and Ethanol Extracts of Leaves, Seeds, and Roots from C. cajan}

Dried roots, leaf and seeds of C. cajan (Taitung No. 3) were collected from Taitung District Agricultural Research and Extension Station, Council of Agriculture (Taitung, Taiwan). Leaves, seeds, and roots of $C$. cajan were rinsed with running water to remove soil. The surface of the leaves, seeds, and roots were sterilized in $75 \%$ ethanol for $3 \mathrm{~min}$ and then rinsed three times in sterile distilled water; then grind to powder. Dried roots, leaf and seeds of $C$. cajan $(500 \mathrm{~g})$ were extracted with 1:20 ratio $(w / v)$ of $98 \pm 2{ }^{\circ} \mathrm{C}$ hot water $(10 \mathrm{~L})$ for $3 \mathrm{~h}$ or extracted with $1: 20$ ratio $50 \%, 95 \%$ ethanol by soaking in the room temperature for $72 \mathrm{~h}$. After filtering through Whatman No. 2 filter paper, the filtrates were concentrated (10-fold) under reduced pressure and lyophilized to obtain the hot water extracts of leaves, seeds, and roots (HWCL, HWCS, HWCR), 50\% ethanol extract of leaves, seeds, and roots (EECL50, EECS50, EECR50).

\subsection{Determination of Basic Nutritional and Amino Acid Compositions}

Nutritional values of leaves, seeds, and roots of $C$. cajan including moisture, protein, fat, fiber, ash, carbohydrate and mineral $(\mathrm{Na}, \mathrm{Zn}, \mathrm{Mg}, \mathrm{Mn}, \mathrm{Fe}, \mathrm{Cu}, \mathrm{Ca})$ contents were analyzed following the Association of Official Analytical Communities (AOAC; (2000)) guidelines [9]. Amino acid compositions of C. cajan were determined as described in AOAC 994.12 [10].

\subsection{Determination of Total Phenolic Content (TPC)}

TPC was determined by the Folin Ciocalteu method following the literature method of Do et al. [11]. Briefly, $1 \mathrm{~mL}$ of extract (100-500 $\mu \mathrm{g} / \mathrm{mL})$ solution was mixed with $2.5 \mathrm{~mL}$ of $10 \%(w / v)$ Folin-Ciocalteu reagent. After $5 \mathrm{~min}, 2.0 \mathrm{~mL}$ of $\mathrm{Na}_{2} \mathrm{CO}_{3}(75 \%)$ was subsequently added to the mixture and incubated at $50{ }^{\circ} \mathrm{C}$ for $10 \mathrm{~min}$ with intermittent agitation. Afterwards, the sample was cooled and the absorbance was measured utilizing a UV spectrophotometer (UV-1800, Shimadzu, Kyoto, Japan) at $765 \mathrm{~nm}$ against a blank without extract. The TPC value was expressed as micrograms of gallic acid equivalent per gram of extract (mg gallic acid (GAE)/g dry extract).

\subsection{Determination of Total Flavonoid Content (TFC)}

TFC of each extract investigated by using the aluminum chloride colorimetric method described in Do et al. [11] with slight modifications. An aliquot of $1 \mathrm{~mL}$ of extract solution $(1-500 \mathrm{~g} / \mathrm{mL})$ or quercetin $(25-200 \mu \mathrm{g} / \mathrm{mL})$ were mixed with $0.2 \mathrm{~mL}$ of $10 \%(w / v) \mathrm{AlCl}_{3}$ solution in methanol, $0.2 \mathrm{~mL}$ $(1 \mathrm{M})$ potassium acetate and $5.6 \mathrm{~mL}$ distilled water. The mixture was incubated for $30 \mathrm{~min}$ at room temperature followed with the measurement of absorbance at $415 \mathrm{~nm}$ against the blank. Results were expressed as micrograms of quercetin equivalent per gram of extract (mg Quercetin (QUE)/g dry extract).

\subsection{Antioxidant Activities of C. cajan}

\subsubsection{1,1-Diphenyl-2-picrylhydrazyl Radical (DPPH) Scavenging Effects Assay}

The radical scavenging activity of the extracts was adopted to measure antioxidant activity using the DPPH method [11]. Briefly, $2 \mathrm{~mL}$ of extract solution $(1-500 \mu \mathrm{g} / \mathrm{mL})$ in methanol was added to $2 \mathrm{~mL}$ of DPPH $(0.1 \mathrm{mM})$ solution. The mixtures were kept aside in a dark area for $30 \mathrm{~min}$ and absorbance was measured at $\max 517 \mathrm{~nm}$ against an equal amount of DPPH and methanol as a blank. The percentage of DPPH scavenging was estimated using the equation (1):

$$
\% \text { scavenging of } D P P H=((A 0-A 1) / A 0) \times 100
$$

where $\mathrm{A}_{0}=$ absorbance of the control and $\mathrm{A}_{1}=$ absorbance of the test extracts. The $\mathrm{IC}_{50}$ value is the half-maximal inhibit concentration as the amount of antioxidant required to decrease the initial DPPH concentration by $50 \%$. 


\subsubsection{Nitric Oxide (NO) Scavenging Effects Assay}

The NO radical scavenging activity was measured applying the method presented in Marcocci et al. [12] with slight modifications. Aliquots of $4 \mathrm{~mL}$ of extract solutions $(1-500 \mu \mathrm{g} / \mathrm{mL})$ were added to $1 \mathrm{~mL}$ of sodium nitroprusside solution $(25 \mathrm{mM})$ in a test tube and then incubated at $37^{\circ} \mathrm{C}$ for $2 \mathrm{~h}$. A $0.5-\mathrm{mL}$ portion of the incubation solution was removed and diluted with $0.3 \mathrm{~mL}$ of Griess reagent. The absorbance of the chromophore formed during the diazotization of nitrite with sulfanilamide and subsequent coupling with naphthylethylenediamine dihydrochloride was immediately read at $570 \mathrm{~nm}$ and referred to the absorbance of standard solutions of sodium nitrite salt treated in the same way with Griess reagent.

\subsection{3. $\mathrm{ABTS}^{+}$Scavenging Effects Assay}

The antioxidant capacity was determined by applying a spectrophotometric method described in Jeannine et al. [13]. In this assay, 2,20-azino-bis(3-ethylbenzothiazoline-6-sulfonic acid) diammonium salt (ABTS) solution was mixed with potassium persulfate and left in the dark for $12 \mathrm{~h}$ before use. Samples $(10 \mu \mathrm{L}$, concentration of $1-500 \mu \mathrm{g} / \mathrm{mL})$ were added to the ABTS methanol solution $(1 \mathrm{~mL})$ and the absorbance was measured after $6 \mathrm{~min}$. The ABTS radical scavenging ability was calculated with this equation: $\left(\left(A_{0}-A_{1}\right) / A_{0}\right) \times 100$, where $A_{0}$ is the absorbance of the control and $A_{1}$ is the absorbance in the presence of the samples. The $\mathrm{IC}_{50}$ value was half-maximal inhibit concentration as the amount of antioxidant required to decrease the initial ABTS concentration by $50 \%$.

\subsubsection{Ferric Reducing Antioxidant Power (FRAP) Assay}

FRAP values of the individual extracts that reflect their antioxidant activity were determined using the modified $\mathrm{Fe}^{3+}$ to $\mathrm{Fe}^{2+}$ reduction assay [14]. Briefly, $1 \mathrm{~mL}$ of extract solution $(1-500 \mu \mathrm{g} / \mathrm{mL})$ in methanol was added to $2.5 \mathrm{~mL}$ of $0.2 \mathrm{M}$ sodium phosphate buffer ( $\mathrm{pH} 6.6)$ and $2.5 \mathrm{~mL}$ of $1 \%(w / v)$ potassium ferricyanide $\left(\mathrm{K}_{3} \mathrm{Fe}(\mathrm{CN})_{6}\right)$ solution. The mixture was vortexed and incubated at $50{ }^{\circ} \mathrm{C}$ for $20 \mathrm{~min}$ assisted with a vortex shaker followed by the addition of $2.5 \mathrm{~mL} \mathrm{10 \% (w/v)} \mathrm{trichloroacetic} \mathrm{acid}$ and centrifugation at $3000 \mathrm{rpm}$. Finally, $2.5 \mathrm{~mL}$ of the supernatant was mixed with $2.5 \mathrm{~mL}$ deionized water and $0.5 \mathrm{~mL} 0.1 \%(w / v)$ ferric chloride, and Perl's Prussian blue color was measured at $700 \mathrm{~nm}$ against a blank. Increased absorbance of the reaction mixture indicated greater reducing power.

\subsection{Anti-Hyperglycemic Activities of C. cajan Roots (CCR)}

\subsubsection{Inhibition of $\alpha$-Amylase Activity Assay}

The assay was done as illustrated by Shu et al. [15] with some modifications. Briefly, $50 \mu \mathrm{L}$ of sample in $0.02 \mathrm{M}$ phosphate buffer ( $\mathrm{pH} 6.9$, containing $0.006 \mathrm{M} \mathrm{NaCl}$ ) was mixed with $25 \mu \mathrm{L}$ of $\alpha$-amylase at a final concentration of $2.5 \mathrm{mU} / \mathrm{mL}$ and incubated at $25^{\circ} \mathrm{C}, 10 \mathrm{~min}$. Then, $50 \mu \mathrm{L}$ of starch solution $(0.5 \%(w / v), 0.02 \mathrm{M}$ phosphate buffer, $\mathrm{pH} 6.9$, containing $0.006 \mathrm{M} \mathrm{NaCl})$ was added and incubated $10 \mathrm{~min}, 25^{\circ} \mathrm{C}$. Then, $100 \mu \mathrm{L}$ 3,5-dinitrosalicylic acid (DNS) color reagent was added to stop the reaction (100 mg DNS dissolved in $3 \mathrm{~mL}$ distilled water, to this $3 \mathrm{~g} \mathrm{KNaC}_{4} \mathrm{H}_{4} \mathrm{O}_{6} \cdot 4 \mathrm{H}_{2} \mathrm{O}$, and $2 \mathrm{~mL}$ of $\mathrm{NaOH}(2 \mathrm{M})$ were added; the solution was diluted to $10 \mathrm{~mL}$ with distilled water) and immediately kept in water bath $100^{\circ} \mathrm{C}$ for $10 \mathrm{~min}$. The absorbance of the resultant solution was taken at $540 \mathrm{~nm}$. The uninhibited enzyme was taken as control. A suitable blank (phosphate buffer and starch solution) was used for all the samples.

\subsubsection{Inhibition of $\alpha$-Glucosidase Activity Assay}

The slightly modified method of McCue et al. [16]. In brief, in a 96-well microplate, $50 \mu \mathrm{L}$ $\alpha$-glucosidase $(1.0 \mathrm{U} / \mathrm{mL})$ in phosphate buffer $\left(0.1 \mathrm{M}, \mathrm{pH}\right.$ 6.8) for $10 \mathrm{~min}$ at $37^{\circ} \mathrm{C}$ was incubated with $50 \mu \mathrm{L}$ of samples of various concentrations. The reaction was prompted by addition of $50 \mu \mathrm{L}$ of $5 \mathrm{mM}$, p-Nitrophenyl- $\alpha$-D-glucopyranoside in a $0.1 \mathrm{M}$ phosphate buffer at $\mathrm{pH}$ 6.8. P-nitrophenol's 
release kinetics were read with a microplate spectrophotometric reader Multiskan MS ${ }^{\mathrm{TM}}$ (Labsystems, Minneapolis, MO, USA) for 5 min at intervals of $30 \mathrm{~s}$ and absorbance was measured at $405 \mathrm{~nm}$. The half maximal inhibitory concentration $\left(\mathrm{IC}_{50}\right)$ of extract was then estimated from the concentration-dependent graph. That is the inhibitor concentration against the percent activity is plotted ((I)-Activity \% graph). Using the linear $(y=m x+n)$ equation on this graph for $y=50$ value $\times$ point becomes the $\mathrm{IC}_{50}$ value.

\subsubsection{Anti-Glycation Assay (Advanced Glycation End Products (AGEs) Formation)}

The glycosylation of bovine serum albumin BSA was carried out in accordance with a literature method [17] with some modifications. Extract solution $(1-500 \mu \mathrm{g} / \mathrm{mL})$ was incubated in $10 \mathrm{mg} / \mathrm{mL}$ BSA with $1.1 \mathrm{M}$ glucose in $0.1 \mathrm{M}$ phosphate buffer at $\mathrm{pH} 7.4$ containing $0.2 \%$ sodium azide at $37^{\circ} \mathrm{C}$ for 1,2 , 3 , and 4 weeks. The formation of glycated BSA was determined at an excitation wavelength of $355 \mathrm{~nm}$ and emission of $460 \mathrm{~nm}$ (GENios, TECAN, Neustadt, Germany). Aminoguanidine (AMG) was used as a positive control.

\subsection{Antimicrobial Activity}

The MIC of extracts was determined using a micro dilution method, as described by Song et al. [18]. Inoculum suspensions were prepared from 18 to $24 \mathrm{~h}$ broth cultures. Diluted $100 \mu \mathrm{L}$ suspensions of each bacterial strain were added to $100 \mu \mathrm{L}$ of various concentrations of extracts diluted with broth to obtain a final bacterial count of approximately $1-1.5 \times 10^{6} \mathrm{CFU} / \mathrm{mL}$. The final concentrations of extracts ranged from $5 \mu \mathrm{g} / \mathrm{mL}$ to $500 \mu \mathrm{g} / \mathrm{mL}$ in a series of two-fold dilutions. The MIC was defined as the lowest concentration that restricted bacterial growth to an absorbance lower than 0.05 at $550 \mathrm{~nm}$.

\subsection{Statistical Analysis}

All statistical analyses were performed using SPSS for Windows, version 18 (SPSS, Inc., Chicago, IL, USA). Data are expressed as means \pm standard deviation (SD) and analyzed using one-way ANOVA followed by Duncan's multiple range test. $p<0.05$ is considered statistically significant.

\section{Results}

\subsection{Basic Nutritional Composition of C. cajan}

The basic nutritional compositions of leaves, seeds, and roots are presented in Table 1. Moisture, ash, protein, and fat contents of seeds were all higher than those of leaves and roots. Roots have higher carbohydrate content (contained carbohydrate and fiber) $(90.3 \mathrm{~g} / 100 \mathrm{~g})$ than leaves and seeds. Sugar was not detected in leaves, seeds, and roots of $C$. cajan. The seeds and roots contained high amounts of magnesium $(138.8,130.0 \mathrm{mg} / 100 \mathrm{~g})$ and calcium $(581,597 \mathrm{mg} / 100 \mathrm{~g})$. 
Table 1. The basic nutritional composition of leaves, seeds, and roots of C. cajan.

\begin{tabular}{lccc}
\hline \multirow{2}{*}{ Nutrients } & \multicolumn{3}{c}{ C. cajan (per 100 g) } \\
\cline { 2 - 4 } & Leaves & Seeds & Roots \\
\hline Water (g) & $11.5 \pm 0.2^{\mathrm{b} 2}$ & $14.3 \pm 0.1^{\mathrm{c}}$ & $3.3 \pm 0.1^{\mathrm{a}}$ \\
Crude ash (g) & $3.6 \pm 0.1^{\mathrm{a}}$ & $12.0 \pm 0.0^{\mathrm{b}}$ & $3.6 \pm 0.2^{\mathrm{a}}$ \\
Crude protein (g) & $19.4 \pm 0.5^{\mathrm{b}}$ & $22.0 \pm 0.4^{\mathrm{c}}$ & $2.4 \pm 0.1^{\mathrm{a}}$ \\
Crude fat (g) & $\mathrm{ND}^{1}$ & $5.5 \pm 0.3^{\mathrm{b}}$ & $0.4 \pm 0.0^{\mathrm{a}}$ \\
Carbohydrate (g) & $65.6 \pm 0.2^{\mathrm{b}}$ & $56.2 \pm 0.3^{\mathrm{a}}$ & $90.3 \pm 0.1^{\mathrm{c}}$ \\
\hline Sugar (g) & $\mathrm{ND}$ & $\mathrm{ND}$ & $\mathrm{ND}$ \\
Sodium (mg) & $19.7 \pm 39.0^{\mathrm{a}}$ & $32.5 \pm 5.5^{\mathrm{b}}$ & $108.0 \pm 7.6^{\mathrm{c}}$ \\
Zinc (mg) & $2.1 \pm 0.9^{\mathrm{b}}$ & $0.7 \pm 0.2^{\mathrm{a}}$ & $0.7 \pm 0.9^{\mathrm{a}}$ \\
Magnesium (mg) & $111 \pm 9.5^{\mathrm{a}}$ & $138.8 \pm 7.2^{\mathrm{b}}$ & $130 \pm 8.7^{\mathrm{b}}$ \\
Manganese (mg) & $\mathrm{ND}$ & $6.8 \pm 5.2^{\mathrm{b}}$ & $0.7 \pm 0.2^{\mathrm{a}}$ \\
Iron (mg) & $4.8 \pm 2.1^{\mathrm{a}}$ & $51.5 \pm 8.7^{\mathrm{b}}$ & $\mathrm{ND}$ \\
Copper (mg) & $\mathrm{N} . \mathrm{D}$ & $1.4 \pm 0.6^{\mathrm{a}}$ & $1.0 \pm 0.6^{\mathrm{a}}$ \\
Calcium (mg) & $33 \pm 4.9^{\mathrm{a}}$ & $581 \pm 1.3^{\mathrm{b}}$ & $597 \pm 2.5^{\mathrm{c}}$ \\
\hline
\end{tabular}

${ }^{1}$ ND: not detectable; ${ }^{2}$ Value (means $\pm \mathrm{SD}, n=3$ ) in each row not sharing the same superscript letter are significant difference $(p<0.05)$.

\subsection{Amino Acid Composition of C. cajan}

As the results in Table 2 show, the total amino acid contents of leaves, seeds and roots from C. cajan were $6188.0,6657.9$ and $4452.4 \mathrm{mg} / 100 \mathrm{~g}$, and their essential amino acid contents were $3467.3,3696.5$ and $2232.8 \mathrm{mg} / 100 \mathrm{~g}$, respectively. It is worth noting that the leaves, seeds and roots of $C$. cajan contain a high content of branched chain amino acids (BCAA), which are 1334, 1743, and $1146 \mathrm{mg} / 100 \mathrm{~g}$, respectively.

Table 2. The amino acids composition of leaves, seeds, and roots from C.cajan

\begin{tabular}{|c|c|c|c|}
\hline \multirow{2}{*}{ Amino Acids } & \multicolumn{3}{|c|}{ Amino Acids Contents (mg/100 g) } \\
\hline & Leaves & Seeds & Roots \\
\hline Alanine & $576.5 \pm 5.6^{\mathrm{a}}$ & $1547.8 \pm 3.9^{c}$ & $687.5 \pm 12.3^{b}$ \\
\hline Glutamine & $808.8 \pm 10.3^{b}$ & $648.3 \pm 6.3^{\mathrm{a}}$ & $871.8 \pm 11.2^{c}$ \\
\hline Arginine * & $333.4 \pm 1.3^{c}$ & $279.9 \pm 2.6^{b}$ & $226.1 \pm 5.9^{a}$ \\
\hline Leucine ${ }^{*}$ & $597.8 \pm 3.8^{b}$ & $679.7 \pm 13.5^{c}$ & $492.2 \pm 4.2^{\mathrm{a}}$ \\
\hline Isoleucine * & $314.1 \pm 8.3^{b}$ & $392.0 \pm 3.1^{c}$ & $272.7 \pm 4.2^{\mathrm{a}}$ \\
\hline Valine * & $422.2 \pm 3.6^{b}$ & $671.4 \pm 4.8^{c}$ & $381.1 \pm 5.6^{a}$ \\
\hline Lysine * & $425.4 \pm 10.1^{b}$ & $740.8 \pm 6.3^{c}$ & $297.9 \pm 2.0^{a}$ \\
\hline Phenylalanine * & $612.4 \pm 3.6^{\mathrm{c}}$ & $354.7 \pm 7.6^{\mathrm{b}}$ & $262.1 \pm 2.5^{a}$ \\
\hline Histidine * & $266.8 \pm 1.3^{b}$ & $361.7 \pm 3.6^{c}$ & $118.4 \pm 4.3^{\mathrm{a}}$ \\
\hline Proline & $137.9 \pm 1.2^{\mathrm{c}}$ & $72.1 \pm 8.2^{a}$ & $89.1 \pm 8.1 \mathrm{ab}$ \\
\hline Glycine & $235.7 \pm 2.8^{c}$ & $160.7 \pm 3.4^{b}$ & $139.7 \pm 6.9^{a}$ \\
\hline Tyrosine & $143.9 \pm 3.9^{\mathrm{a}}$ & $186.1 \pm 2.0^{\mathrm{b}}$ & $149.8 \pm 5.2^{a}$ \\
\hline Serine & $494.6 \pm 4.8^{c}$ & $220.0 \pm 8.1^{b}$ & $169.2 \pm 4.5^{\mathrm{a}}$ \\
\hline Methionine * & $86.0 \pm 2.3^{c}$ & $70.6 \pm 1.6^{b}$ & $61.1 \pm 1.2^{\mathrm{a}}$ \\
\hline Threonine * & $406.8 \pm 1.3^{c}$ & $136.2 \pm 5.4^{b}$ & $119.9 \pm 4.6^{a}$ \\
\hline Aspartic acid & $323.3 \pm 5.2^{c}$ & $126.4 \pm 1.7^{b}$ & $112.5 \pm 5.2^{a}$ \\
\hline Tryptophan * & $2.4 \pm 0.4^{\mathrm{ab}}$ & $9.5 \pm 0.1^{c}$ & $1.3 \pm 0.4^{\mathrm{a}}$ \\
\hline Cysteine & $\mathrm{ND}^{1}$ & ND & ND \\
\hline Total & $6188 \pm 39$ & $6657.9 \pm 36$ & $4452.4 \pm 22$ \\
\hline $\mathrm{BCAA}^{* *}$ & $1334 \pm 16$ & $1743 \pm 21$ & $1146 \pm 18$ \\
\hline
\end{tabular}

* Essential Amino acid; ${ }^{* *}$ Branched Chain Amino Acid; ${ }^{1}$ ND: not detectable; ${ }^{1}$ Value (means \pm SD, $n=3$ ) in each row not sharing the same superscript letter are significant difference $(p<0.05)$. 


\subsection{Yields, TPC and TFC of Hot Water and 50\% Ethanol Extracts from Various Part of C. cajan}

Table 3 shows that yields of leaves, seeds, and root extracts of $C$. cajan by hot water were in the range from $8.9-10.2 \%$ and by $50 \%$ ethanol they were in the range from $4.3-7.2 \%$. The extracts from the roots, seeds and leaves of $C$. cajan extracted with $50 \%$ ethanol contain higher TPC and TFC than its hot water extract.

Table 3. Yields, total polyphenol (TPC) and flavonoid (TFC) contents of hot water and 50\% ethanol extracts from various parts of C. cajan.

\begin{tabular}{ccccc}
\hline \multirow{2}{*}{ Leaves } & Extracts & Yields (\%) & TPC (mg GAE/g dw) & TFC (mg QUE/g dw) \\
\hline \multirow{2}{*}{ Seeds } & HWCL $^{1}$ & $10.2 \pm 0.5^{\mathrm{b}} 4$ & $7.23 \pm 0.05^{\mathrm{a}}$ & $0.22 \pm 0.06^{\mathrm{a}}$ \\
& EECL50 $^{*}$ & $7.2 \pm 0.6^{\mathrm{b}}$ & $13.5 \pm 0.06^{\mathrm{b}}$ & $10.4 \pm 0.24^{\mathrm{b}}$ \\
\hline \multirow{2}{*}{ Roots } & HWCS $^{2}$ & $8.9 \pm 0.2^{\mathrm{b}}$ & $10.93 \pm 0.9^{\mathrm{b}}$ & $0.97 \pm 0.20^{\mathrm{a}}$ \\
& EECS50 $^{*}$ & $5.1 \pm 0.3^{\mathrm{a}}$ & $23.15 \pm 0.15^{\mathrm{c}}$ & $15.13 \pm 0.12^{\mathrm{b}}$ \\
\hline & HWCR $^{3}$ & $9.2 \pm 0.8^{\mathrm{b}}$ & $16.24 \pm 0.13^{\mathrm{b}}$ & $7.32 \pm 0.40^{\mathrm{a}}$ \\
\hline
\end{tabular}

${ }^{1}$ HWCL hot water extracts; EECL50 50\% ethanol extracts of leaves; ${ }^{2}$ HWCS hot water extracts; EECS50: 50\% ethanol extracts of seeds; ${ }^{3}$ HWCR hot water extracts; EECR50 50\% ethanol extracts of roots of C. cajan; ${ }^{4}$ Value (means $\pm \mathrm{SD}, n=3)$ in each column not sharing the same superscript letter are significant difference $(p<0.05)$.

In addition, the contents of hot water and 50\% ethanol extracts of roots (HWCR, EECR50) have higher TPC and TFC contents than the other parts of C. cajan. EECR50 had higher TPC and TFC contents than those of HWCR, the TPC and TFC contents of EECR50 were $27.15 \mathrm{mg} \mathrm{GAE} / \mathrm{g} \mathrm{dw}$ and $16.87 \mathrm{mg}$ QUE/g dw, respectively, and the TPC and TFC contents of HWCR were only $16.24 \mathrm{mg} \mathrm{GAE} / \mathrm{g} \mathrm{dw}$ and $7.32 \mathrm{mg}$ QUE/g dw.

\subsection{Antioxidant Activities of C. cajan Extracts}

As the result in Table 4 show, the DPPH scavenging effects of $50 \%$ ethanol extracts (EECR, EECS, and EECL) were higher than those of hot water extracts of C. cajan (HWCR, HWCS, and HWCL). EECR had a higher effect in the DPPH assay $\left(\mathrm{IC}_{50}=640 \mu \mathrm{g} / \mathrm{mL}\right)$ than the other extracts. In addition, the inhibitory effect of EECR on NO production in LPS-induced macrophage was also better than that of the EECL and EECS, the $\mathrm{IC}_{50}$ was 51,217 and $512 \mu \mathrm{g} / \mathrm{g}$, respectively $(p<0.05)$.

Table 4. The DPPH scavenging and the inhibition of NO formation effects of hot water and $50 \%$ ethanol extract of leaves, seeds, and roots from C. cajan.

\begin{tabular}{ccc}
\hline Extracts & $\begin{array}{c}\text { DPPH Scavenging Effects } \\
\left(\text { IC }_{\mathbf{5 0}} \text { Value, } \boldsymbol{\mu g} / \mathbf{m L}\right)\end{array}$ & $\begin{array}{c}\text { NO Scavenging Effects } \\
\left(\mathbf{I C}_{\mathbf{5 0}} \text { Value, } \boldsymbol{\mu} \mathbf{g} / \mathbf{m L}\right)\end{array}$ \\
\hline \multicolumn{3}{c}{ Hot Water Extracts } \\
\hline HWCR ${ }^{1}$ & $736 \pm 15^{\mathrm{b}}$ & $145 \pm 6^{\mathrm{b}}$ \\
HWCS & $2536 \pm 51^{\mathrm{d}}$ & $1250 \pm 23^{\mathrm{f}}$ \\
HWCL & $752 \pm 12^{\mathrm{b}}$ & $650 \pm 20^{\mathrm{e}}$ \\
\hline \multicolumn{3}{c}{$50 \%$ ethanol extracts $^{\mathrm{c}}$} \\
\hline EECR50 & $640 \pm 16^{\mathrm{a}}$ & $51 \pm 4^{\mathrm{a}}$ \\
EECS50 & $1263 \pm 31^{\mathrm{c}}$ & $512 \pm 16^{\mathrm{d}}$ \\
EECL50 & $675 \pm 13^{\mathrm{a}}$ & $217 \pm 12^{\mathrm{c}}$ \\
\hline
\end{tabular}

${ }^{1}$ HWCR, HWCS, and HWCL hot water extracts of C. cajan (L.) Millsp roots, seeds, and leaves; EECR, EECS, and EECL $50 \%$ ethanol extract of C. cajan (L.) Millsp roots, seeds, and leaves; ${ }^{2}$ Values (means \pm SD, $n=3$ ) in each column not sharing the same superscript letter are significant difference $(p<0.05)$. 
3.5. The Ccorrelation of Antioxidant Activity and Phenolic Compounds of 50\% Ethanol Extracts of Leaves, Seeds, and Roots from C. cajan

The correlations between phenolic compounds and antioxidant activity of EECR are shown in Table 5. The antioxidant activity was high and positive correlation with the content of total phenolic compounds. The correlation coefficients ( $\mathrm{r}$ values) of TPC and TFC for DPPH free radicals scavenging effects were 0.7411 and $0.6340 \mathrm{r}$ values for $\mathrm{NO}$ scavenging effects were 0.6069 and 0.5032 , respectively. TPC has higher $r$ values with TPC (0.9345) in 50\% ethanol extracts of leaves, seeds, and roots of $C$. cajan, and DPPH scavenging effects and NO scavenging effects also have a fairly high correlation coefficient $(\mathrm{r}=0.9023)$.

Table 5. Correlation of antioxidant activity and phenolic compounds of $50 \%$ ethanol extracts of leaves, seeds, and roots from C. cajan.

\begin{tabular}{ccccc}
\hline Correlation $(\mathbf{r})$ & TPC $(\mathbf{m g} / \mathbf{g ~ d w})$ & TFC $(\mathbf{m g} / \mathbf{g ~ d w})$ & $\begin{array}{c}\text { DPPH Scavenging } \\
\text { Effects }^{\left(\text {IC }_{50}\right)}\end{array}$ & $\begin{array}{c}\text { NO Scavenging } \\
\text { Effects }_{\left(\mathrm{IC}_{50}\right)}\end{array}$ \\
\hline TPC $(\mathrm{mg} / \mathrm{g} \mathrm{dw})$ & 1 & - & - & - \\
TFC $(\mathrm{mg} / \mathrm{g} \mathrm{dw})$ & $0.9345^{* *}$ & 1 & - & - \\
DPPH scavenging effects $\left(\mathrm{IC}_{50}\right)$ & $0.7411^{* *}$ & $0.6340^{*}$ & 1 & - \\
NO scavenging effects (IC50) & $0.6069^{*}$ & $0.5032^{*}$ & $0.9023^{* *}$ & 1 \\
\hline
\end{tabular}

* are significantly different at $p<0.05 ;{ }^{* *}$ are significantly different at $p<0.01$.

\subsection{Antioxidant Effects of Hot Water and Ethanol Extracts of C. cajan Roots}

In order to further explore the antioxidant effects of hot water and ethanol extract of CCR, DPPH, $\mathrm{ABTS}^{+}$scavenger effects and FRAP were evaluated. Table 6 shows that EECR95 had the best antioxidant activity regardless of the different antioxidant evaluation methods, and the $\mathrm{IC}_{50}$ of DPPH and ABTS scavenger effects were 460 , and $100 \mu \mathrm{g} / \mathrm{mL}$, which were much better than those of HWCR and EECR50. Besides, EECR95 also had higher reducing power on FRAP assay than that of EECR50 and HWCR, their $\mathrm{EC}_{50}$ were 929,1131 and $2159 \mu \mathrm{g} / \mathrm{mL}$, respectively $(p<0.05)$.

Table 6. The antioxidant activity of hot water, 50 and $95 \%$ ethanol extracts of $C$. cajan roots.

\begin{tabular}{cccc}
\hline \multirow{2}{*}{ Extracts } & \multicolumn{2}{c}{ IC $_{\mathbf{5 0}}$ Values $(\mu \mathrm{g} / \mathbf{m L})$} & EC $_{\mathbf{5 0}}$ Values $(\mu \mathrm{g} / \mathrm{mL})$ \\
\cline { 2 - 4 } & DPPH & ABTS $^{+3}$ & FRAP \\
\hline HWCR $^{1}$ & $928 \pm 62^{\mathrm{c} 2}$ & $4771 \pm 89^{\mathrm{c}}$ & $2158 \pm 45^{\mathrm{b}}$ \\
EECR50 & $677 \pm 25^{\mathrm{b}}$ & $184 \pm 21^{\mathrm{b}}$ & $1131 \pm 84^{\mathrm{a}}$ \\
EECR95 & $460 \pm 56^{\mathrm{a}}$ & $100 \pm 13^{\mathrm{a}}$ & $929 \pm 78^{\mathrm{a}}$ \\
\hline
\end{tabular}

${ }^{1}$ HWCR hot water extracts; EECR50, and EECR95 50\% and 95\% ethanol extracts of C. cajan; ${ }^{2}$ Value (means \pm $\mathrm{SD}, n=3)$ in each column not sharing the same superscript letter are significant difference $(p<0.05) .{ }^{3}$ ABTS $^{+}$: 2,2'-azinobis (3-ethylbenzothiazoline-6-sulfonic acid) radical cation.

\subsection{Hypoglycemic Effects of Hot Water and Ethanol Extracts of C. cajan Roots}

Table 7 shows the inhibiory effects of hypoglycemic effects of HWCR, EECR50 and EECR95. The results indicated that EECR95 had the best hypoglycemic effects on $\alpha$-glucosidase and $\alpha$-amylase activities and anti-glycation effects than EECR50 and EECR95 $\left(\mathrm{IC}_{50}=39,120\right.$ and $229 \mu \mathrm{g} / \mathrm{mL}$, respectively). $\alpha$-glucosidase and $\alpha$-amylase activities of EECR95 were even better than acarbose (an inhibitor of $\alpha$-glucosidase activity in the intestine, which is clinically used for the treatment of diabetes). In addition, the anti-glycation effects of EECR95 also was comparable to the ability of aminoguanidine (AMG, a drug known to inhibit the formation of AGEs) $(p<0.05)$. 
Table 7. The anti-hyperglycemic effects of hot water, 50 and $95 \%$ ethanol extracts from C. cajan roots.

\begin{tabular}{cccc}
\hline \multirow{2}{*}{ Extracts/Standards } & \multicolumn{3}{c}{ IC $_{\mathbf{5 0} \text { Values }(\mu \mathrm{g} / \mathrm{mL})}$} \\
\cline { 2 - 4 } & $\alpha$-Glucosidase Activity & $\alpha$-Amylase Activity & $\begin{array}{c}\text { Anti-Glycation } \\
\text { (AGEs Formation) }\end{array}$ \\
\hline Acarbose $^{1}$ & $303 \pm 12^{\mathrm{d} 4}$ & $970 \pm 52^{\mathrm{c}}$ & - \\
AMG $^{2}$ & - & - & $220 \pm 12^{\mathrm{a}}$ \\
HWCR $^{3}$ & $256 \pm 11^{\mathrm{c}}$ & $957 \pm 24^{\mathrm{c}}$ & $1865 \pm 103^{\mathrm{c}}$ \\
EECR50 $^{\text {EECR95 }}$ & $127 \pm 9^{\mathrm{b}}$ & $320 \pm 22^{\mathrm{b}}$ & $532 \pm 36^{\mathrm{b}}$ \\
\hline
\end{tabular}

1 Acarbose an inhibitor of $\alpha$-glucosidase activity in the intestine, which is clinically used for the treatment of diabetes; ${ }^{2}$ AMG (Aminoguanidine): A drug known to inhibit the formation of AGEs; ${ }^{3}$ HWCR: hot water extracts, EECR50, and EECR95 $50 \%$ and $95 \%$ ethanol extracts of $C$. cajan roots; ${ }^{4}$ Value (means \pm SD, $n=3$ ) in each column not sharing the same superscript letter are significant difference $(p<0.05)$.

\subsection{Anti-Microbial Effects of Hot Water and Ethanol Extracts of C. cajan Roots}

As the results in Table 8 show, HWCR had no antibacterial ability, however, EECR50 and EECR95 have excellent antibacterial effects, among which EECR95 still had the best effect, and it has the best inhibitory effect on $P$. gingivalis periodonogen (anaerobic culture) (MIC $=16 \mu \mathrm{g} / \mathrm{mL}$ ), followed by S. mutans and E. coli (MIC was about 100 and $113 \mu \mathrm{g} / \mathrm{mL}$, respectively). Even though EECR95 had the lowest anti-microbial effect on S. aureus, its MIC was only about $180 \mu \mathrm{g} / \mathrm{mL}(p<0.05)$.

Table 8. The anti-bacterial growth effects of hot water, 50 and $95 \%$ ethanol extracts from C. cajan roots.

\begin{tabular}{ccccc}
\hline \multirow{2}{*}{ Extracts } & \multicolumn{4}{c}{ Anti-Bacterial Growth Effects (MIC, $\mu \mathrm{g} / \mathrm{mL})$} \\
\cline { 2 - 5 } & E. coli & S. aureus & P. gingivalis & S. mutans \\
\hline HWCR $^{1}$ & $\mathrm{ND}^{2}$ & $\mathrm{ND}$ & $\mathrm{ND}$ & $\mathrm{ND}$ \\
EECR50 & $169 \pm 9^{\mathrm{b}} 3$ & $260 \pm 12^{\mathrm{b}}$ & $252 \pm 8^{\mathrm{b}}$ & $180 \pm 11^{\mathrm{b}}$ \\
EECR95 & $113 \pm 9^{\mathrm{a}}$ & $180 \pm 6^{\mathrm{a}}$ & $16 \pm 2^{\mathrm{a}}$ & $100 \pm 3^{\mathrm{a}}$ \\
\hline
\end{tabular}

${ }^{1}$ HWCR hot water extracts; EECR50, and EECR95 50\% and 95\% ethanol extracts of C. cajan roots; ${ }^{2}$ ND: not detectable; ${ }^{3}$ Value (means $\pm \mathrm{SD}, n=3$ ) in each column not sharing the same superscript letter are significant difference $(p<0.05)$.

\section{Discussion}

Cajanus cajan can be planted in arid, poor quality soils, which coupled with its high nutritional value, is of great significance in providing the quality and quantity of human proteins. The literature on the leaves, seeds and roots of $C$. cajan has demonstrated notable anti-inflammatory, anti-bacterial and abirritative properties [3,19]. Pal et al. [3] have reported the biological activities and medicinal properties of C. cajan. However, there is no nutritional and functional comparison between the leaves, seeds, and roots of C. cajan in the same reaction systems at the same time. Thus, the aim of this study was to understand which part of $C$. cajan (leaves, seeds, and roots) has more potential for product development. We chose extraction solvents that are usually traditional used and non-toxic-hot water or ethanol-to obtain the C. cajan extracts. Next, we analyzed the basic nutrition, minerals and amino acids composition of the different parts of $C$. cajan. The anti-oxidant activity of leaves, seeds, and roots of C. cajan was examined. Finally, the best potential extracts were evaluated by antioxidant, hypoglycemic and antibacterial assay methods.

Legumes, a major food of the human diet, may contribute to some of the health benefits associated with this eating pattern. Their health benefits include a low saturated fat content, high content of essential nutrients, richness in important micronutrients (including potassium, magnesium, folate, iron, and zinc) [20] and bioactive compounds [21]. They are responsible for different antioxidant, anticarcinogenic, anti-inflammatory, antidiabetic activities, etc. [21]. Previous studied have reported that sprouts, leaves and seeds of soybean and mung bean contain high amounts of crude proteins, 
amino acids, lipids and minerals [22-24]. They have been shown to possess antioxidant, antimicrobial, anti-inflammatory, antidiabetic and antihypertensive effects [23].

In this study, we found that protein contained in leaves and seeds of C. cajan was about $20 \%$, nearly the same as mung bean (20.97-32.6\%) [25], and lower than soybean sprouts (46\%) [23]. The nutritional value of $C$. cajan was assessed base on its amino acid composition. The seeds (beans) contained the highest total amino acid $(6657.9 \mathrm{mg} / 100 \mathrm{~g})$, total essential amino acid (3696.5 mg/100 g) and BCAA contents $(3696.5 \mathrm{mg} / 100 \mathrm{~g})$. The human body needs BCAAs to function properly but is unable to make them, so dietary intake is essential (about $35 \%$ of the BCAAs in our body are concentrated in muscle tissue). This indicated that seeds of $C$. cajan are an excellent protein source from legumes.

Dietary fiber (soluble and insoluble) has the ability to lower blood cholesterol, improve glucose tolerance and reduce glycemic response. Mallillin et al. [26] indicated that the dietary fiber content of root crops varied from 4.6 to $13.5 \mathrm{~g} / 100 \mathrm{~g}$ and in legumes from 20.9 to $46.9 \mathrm{~g} / 100 \mathrm{~g}$, thus root crops and legumes are good sources of dietary fiber. In particular, the dietary fiber, soluble fiber and insoluble fiber of CCR were 21.8, 2.4 and $19.4 \mathrm{~g} / 100 \mathrm{~g}$, respectively [26]. Brown et al. [27] indicated that soluble fiber can decrease total and LDL cholesterol which is evaluated in 67 controlled trials by meta-analysis. Thus, C. cajan roots may play an important role in cholesterol-lowering effects.

Calcium and magnesium are essential minerals found in the body and play an important physiological role in many of its functions. Magnesium deficiency can cause a variety of pathologies including hypocalcaemia, hypokalemia and cardiac and neurological manifestations. Prolonged magnesium deficiency will cause chronic diseases including diabetes, hypertension, coronary heart disease and osteoporosis [28]. Calcium contributes to bone and teeth health, muscle function, blood clotting, neurotransmission, digestive enzyme; especially it is help bones to develop and grow, keeping the body strong and dense. Legumes contain high levels of calcium and magnesium [19]. Our results also indicated that seeds and roots of C. cajan are rich in calcium (about $600 \mathrm{mg} / 100 \mathrm{~g}$ ) which is much better than soybean $(145 \mathrm{mg} / 100 \mathrm{~g}$ ), and the magnesium level (about $140 \mathrm{mg} / 100 \mathrm{~g}$ ) is comparable to that of soybean $(215 \mathrm{mg} / 100 \mathrm{~g})$. Thus, C. cajan can contribute to health benefits for hypocalcaemia and magnesium deficiency.

Zhao et al. [29] reported that the phenolic compounds are widely distributed in fruits and vegetables have potential antioxidant activities and free radical-scavenging abilities. In this study we found that CCR contains the most abundant content of TPC and TFC, and TPC and TFC obtained by $50 \%$ ethanol extracts is better than that of hot water extracts. Pal et al. [3] reported that the cajaninstilbene acid (3-hydroxy-4-prenylmethoxystilbene-2- carboxylic acid), pinostrobin, vitexin and orientin which were contained in the ethanol extract of $C$. cajan leaves exhibited the antioxidant activities by scavenging DPPH radicals. Vo et al. [8] also indicated that genistein, genistin and cajanol were the major isoflavonoids responsible for the antioxidant and anti-inflammation activity in CCR. The total polyphenol contents in roots and leaves of Astragalus L. (Fabaceae) (a well-known medicinal legumes) ranged from 4.29-7.89 and 5.01-8.25 mg GAE/g DW [30]. Our results found that the content of polyphenols in roots and leaves of $C$. cajan are approximately 5- and 2.5- folds that of Astragalus L., respectively.

The correlation between TPC and antioxidant activity is considered the most representative among the bioactive substances with the activity [29]. According to Dancey and Reidy [31], correlation coefficient values of $0.1-0.3$ are low, $0.4-0.6$ are moderate, and $0.7-1.0$ are high. We further analysed the correlation between the hot water and $50 \%$ ethanol extracts of roots, seeds, leaves of C. cajan with their corresponding antioxidant effects (DPPH and NO scanvenging effects), and found that their antioxidant activities have a moderate correlation with TPC $(r=0.7411,0.6069)$ and TFC $(r=0.6340,0.5032)$. Therefore, it is speculated that polyphenols and flavonoids should be the main active compounds of $C$. cajan.

Plants always have been an exemplary source of drugs because they are rich in bioactive compounds and phytochemicals. Plant polyphenols have gained much attention and popularity 
because of their multiple functions and minimal side/adverse effects [32]. The antidiabetic effect is one of the most intensely studied biological roles of polyphenols, such as flavonoids, terpenoids, saponins, carotenoids, alkaloids, and glycosides [33,34]. An important strategy to control hyperglycemia is by inhibition of the key carbohydrate-digesting enzymes ( $\alpha$-amylase and $\alpha$-glucosidase). The inhibitors of these enzymes can delay the digestion of carbohydrates to reduce the rate of glucose absorption from the small intestinal tract, so as to reduce postprandial blood glucose levels. Thus, the inhibition of $\alpha$-amylase and $\alpha$-glucosidase activities is a key role to evaluate the anti-diabetic potentials of phytochemicals [35].

AGEs are generated as a result of chronic hyperglycemia. Increasing evidence demonstrates that AGEs play a pivotal role in the development and progression of diabetic vascular damage. An effective approach to prevention and treatment must therefore focus not only on early glycemic control, but also on reducing factors related to oxidative stress, and the dietary intake of exogenous AGEs in particular [36]. Thus, we evaluated the anti-diabetic potential of C. cajan by using the inhibition of the key carbohydrate-digesting enzymes ( $\alpha$-amylase and $\alpha$-glucosidase) and anti-glycation (AGEs formation) activities. Our results revealed that EECR95 exhibited the strongest hypoglycemic effects by inhibition the carbohydrate-digesting enzymes ( $\alpha$-glucosidase, $\alpha$-amylase) $\left(\mathrm{IC}_{50}=39\right.$ and $120 \mu \mathrm{g} / \mathrm{mL}$ ) which were much better than that of acarbose ( $\mathrm{IC}_{50}=303$ and $970 \mu \mathrm{g} / \mathrm{mL}$ ), and anti-glycation effects which were approximately equal to that of aminoguanidine $(220 \mu \mathrm{g} / \mathrm{mL})$. Besides, the other C. cajan extracts (EECR50 and HWCR) also present good hypoglycemic potential. Nahar et al. [37] indicated that methanolic extract of CCR had anti-diabetic potential which decreased the blood glucose level in alloxan-induced diabetic mice. They also indicated that the hypoglycemic and antioxidant activity might be closely related with the polyphenolic compounds in methanolic extract of CCR.

In traditional medicine, phytochemicals found in plant extracts have led to the discovery of novel and effective antimicrobial agents. Many studies have pointed out that flavonoids (quercetin, genistein, cajanol etc.) and gallic acid, caffeic acid, etc. have the ability to inhibit the growth of bacteria (such as E. coli, S. aureus) [38,39]. Adamczak et al. [40] also reported that the amount of antibacterial ability in plant extracts is related to the TFC. The present results indicated that EECR95 not only had the most potent antibacterial potential (against P. gingivalis, S. mutans, E. coli, and S. aureus) but also the highest TPC and TFC than other extracts of CR. Thus, it indicated that TPC and TFC are indeed the main active components in the CR.

\section{Conclusions}

In summary, the seeds have the best nutritional properties, such as protein, ash and minerals (calcium, magnesium and iron) than the leaves and roots of C. cajan. In addition, the seeds contain a relatively high level of essential amino acids and BCAAs, both of which are even higher than in soybeans. The antioxidant activity of C. cajan roots is better than that of seeds and leaves. Furthermore, the antioxidant, hypoglycemic and antibacterial effects of EECR95 are superior to those of HWCR andEECR50, and these effects should be related to TPC and TFC in EECR95.

Author Contributions: Formal analysis, investigation, and writing-original draft and data curation S.-E.Y.; T.-L.T.V.; conceptualization N.-C.Y.; methodology, C.-L.C.; material providing C.-I.C.; project administration, supervision, and writing-review \& editing T.-Y.S. All authors have read and agreed to the published version of the manuscript.

Funding: This research was funded by the Ministry of Science and Technology of the Republic of China (ROC), Taiwan, for financially supporting this research under contract No. MOST 106-2320-B-212-002, and partly funded by the Taichung Veterans General Hospital Project, Da-Yeh University Taiwan, R.O.C. under contract No. TCVGH-DYU1088304 and Ministry of Education awards and subsidies to Chienkuo Technology University (CTU-108-RP-BS-001-005-A).

Conflicts of Interest: The authors declare no conflict of interest. 


\section{References}

1. Wu, N.; Kong, Y.; Fu, Y.J.; Zu, Y.G.; Yang, Z.W.; Yang, M.; Peng, X.; Efferth, T. In vitro antioxidant properties, DNA damage protective activity, and xanthine oxidase inhibitory effect of cajaninstilbene acid, a stilbene compound derived from pigeon pea (Cajanus cajan (L.) Millsp.) leaves. J. Agr. Food Chem. 2011, 59, 437-443. [CrossRef] [PubMed]

2. Aiyeloja, A.A.; Bello, O.A. Ethnobotanical potentials of common herbs in Nigeria: A case study of Enugu state. Educ. Res. Rev. 2006, 1, 16-22.

3. Pal, D.; Mishra, P.; Sachanm, N.; Ghosh, A.K. Biological activities and medicinal properties of Cajanus cajan (L) Millsp. J. Adv. Pharm. Technol. Res. 2011, 2, 207-214. [CrossRef] [PubMed]

4. Pandey, I.; Tiwari, S.; Pandey, R.; Kumar, R. Effect of bed configuration, fertilizer levels and placement method on the productivity of long duration Pigeon pea (Cajanus cajan (L) Millsp) under rainfed condition. J. Food Legumes 2014, 27, 206-209.

5. Grover, J.K.; Yadav, S.; Vats, V. Medicinal plants of India with anti-diabetic potential. J. Ethnopharm. 2002, 81, 81-100. [CrossRef]

6. Ahmed, R.; Muhammad, A.; Ahmed, N. Seed germination and seedling growth of pigeon pea (Cajanus cajan (L.) Millsp.) at different salinity regimes. Int. J. Biol. Biotech. 2015, 12, 155-160.

7. Kong, Y.; Fu, Y.J.; Zu, Y.G.; Chang, F.R.; Chen, Y.H.; Liu, X.L.; Stelten, J.; Schiebel, H.M. Cajanuslactone a new coumarin with anti bacterial activity from pigeon pea leaves. Food Chem. 2010, 121, 1150-1155. [CrossRef]

8. Vo, T.L.T.; Yang, N.C.; Yang, S.E.; Chen, C.L.; Wu, C.H.; Song, T.Y. Effects of Cajanus cajan (L.) Millsp. roots extracts on the antioxidant and anti-inflammatory activities. Chin. J. Physiol. 2020, 63, 137-148.

9. AOAC. Official Methods of Analysis of the Association of Official Analytical Chemists, 17th ed.; Horwitz, W., Ed.; AOAC International: Rockville, MD, USA, 2000.

10. AOAC. Official Method 994.12, Amino Acids in Feeds. In Official Methods of Analysis of AOAC Int, 18th ed.; AOAC International: Rockville, MD, USA, 2011; Chapter 4; pp. 9-19.

11. Do, Q.D.; Angkawijaya, A.E.; Tran, N.P.L.; Huynh, L.H.; Soetaredjo, F.E.; Ismadij, S.; Ju, Y.H. Effect of extraction solvent on total phenol content, total flavonoid content, and anti-oxidant activity of Limnophila aromatica. J. Food Drug Anal. 2014, 22, 296-302. [CrossRef]

12. Marcocci, L.; Maguire, J.J.; Droy-Lefaix, M.T.; Packer, L. The nitric oxide-scavenging properties of Ginkgo biloba extract EGB 761. Biochem. Biophys. Res. Commun. 1994, 201, 748-755. [CrossRef]

13. Jeannine, B.; Paulo, J.A. Investigation of the physicochemical, antimicrobial and anti-oxidant properties of gelatin-chitosan edible film mixed with plant ethanolic extracts. J. Food Biosci. 2016, 16, 17-25.

14. Chu, Y.H.; Chang, C.L.; Hsu, H.F. Flavonoid content of several vegetables and their anti-oxidant activity. J. Sci. Food Agric. 2000, 80, 561-567. [CrossRef]

15. Shu, X.S.; Lv, J.H.; Tao, J.; Li, G.M.; Li, H.D.; Ma, N. Antihyperglycemic effects of total flavonoids from Polygonatum odoratum in STZ and alloxan-induced diabetic rats. J. Ethnopharm. 2009, 124, 539-543. [CrossRef] [PubMed]

16. McCue, P.P.; Shetty, K. Inhibitory effects of rosmarinic acid extracts on porcine pancreatic amylase in vitro. Asia Pac. J. Clin. Nutr. 2004, 13, 101-106. [PubMed]

17. Vinson, J.A.; Howard, T.B. Inhibition of protein glycation and advanced glycation end products by ascorbic acid and other vitamins and nutrients. J Nutr. Biochem. 1996, 7, 659-663. [CrossRef]

18. Song, J.H.; Kim, S.K.; Chang, K.W.; Han, S.K.; Yi, H.K.; Jeon, J.G. In vitro inhibitory effects of Polygonum cuspidatum on bacterial viability and virulence factors of Streptococcus mutans and Streptococcus sobrinus. Arch. Oral Biol. 2006, 51, 1131-1140. [CrossRef]

19. Zhang, D.Y.; Zhang, S.; Zu, Y.G.; Fu, Y.J.; Kong, Y.; Gao, Y. Negative pressure cavitation extraction and antioxidant activity of genistein and genistin from the roots of pigeon pea (Cajanus cajan (L.) Millsp.). Sep. Purif. Technol. 2010, 74, 261-270. [CrossRef]

20. Virginia Messina. Nutritional and health benefits of dried beans. Am. J. Clin. Nutr. 2014, 100, 437S-442S. [CrossRef]

21. Alvarado-López, A.N.; Gómez-Oliván, L.M.; Basilio Heredia, J.; BaezaJiménez, R.; Garcia-Galindo, H.S.; Lopez-Martine, L.X. Nutritional and bioactive characteristics of Ayocote bean (Phaseolus coccienus L.): An underutilized legume harvested in Mexico. CyTA J. Food 2019, 17, 199-206. [CrossRef]

22. Ghani, M.; Kulkarni, K.P.; Song, J.T.; Shannon, J.G.; Lee, J.D. Soybean Sprouts: A Review of Nutrient Composition, Health Benefits and Genetic Variation. Plant Breed Biotechnol. 2016, 4, 398-412. [CrossRef] 
23. Tang, D.Y.; Dong, Y.M.; Ren, H.K.; Li, L.; He, C.F. A review of phytochemistry, metabolite changes, and medicinal uses of the common food mung bean and its sprouts (Vigna radiata). Chem. Cent. J. 2014, 8, 4. [CrossRef] [PubMed]

24. Fan, Y.F.; Chen, J.X.; Wang, Z.L.; Tan, T.T.; Li, S.L.; Li, J.F.; Wang, B.B.; Zhang, J.W.; Cheng, Y.J.; Wu, X.L.; et al. Soybean (Glycine max L. Merr.) seedlings response to shading: Leaf structure, photosynthesis and proteomic analysis. BMC Plant Biol. 2019, 19, 34. [CrossRef] [PubMed]

25. Hou, D.Z.; Yousaf, L.R.; Xue, Y.; Hu, J.R.; Wu, J.H.; Hu, X.S.; Feng, N.H.; Shen, Q. Mung Bean (Vigna radiata L.): Bioactive Polyphenols, Polysaccharides, Peptides, and Health Benefits. Nutrients 2019, 11, 1238. [CrossRef]

26. Mallillin, A.C.; Trinidad, T.P.; Raterta, R.; Dagbay, K.; Loyola, A.S. Dietary fiber and fermentability characteristics of root crops and legumes. Br. J. Nutr. 2008, 100, 485-488. [CrossRef] [PubMed]

27. Brown, L.; Rosner, B.; Willett, W.W.; Sacks, F.M. Cholesterol-lowering effects of dietary fiber: A meta-analysis. Am. J. Clin. Nutr. 1999, 69, 30-42. [CrossRef] [PubMed]

28. Swaminathan, R. Magnesium Metabolism and its Disorders. Clin. Biochem. Rev. 2003, 24, 47-66.

29. Zhao, H.X.; Zhang, H.S.; Yang, S.F. Phenolic compounds and its antioxidant activities in ethanolic extracts from seven cultivars of Chinese jujube. Food Sci. Hum. Wellness 2014, 3, 183-190. [CrossRef]

30. Ghaly, A.E.; Alkoaik, F.N. Extraction of Protein from Common Plant Leaves for Use as Human Food. Am. J. Appl. Sci. 2010, 7, 331-342. [CrossRef]

31. Dancey, C.; Reidy, J. Statistics without Maths for Psychology, 8th ed.; University of East London: London, UK, 2020.

32. Bahadoran, Z.; Mirmiran, P.; Azizi, F. Dietary polyphenols as potential nutraceuticals in management of diabetes: A review. J. Diabetes Metab. Disord. 2013, 12, 43-52. [CrossRef]

33. Kooti, W.; Moradi, M.; Akbari, S.; Sharafi-Ahvazi, N.; AsadiSamani, M.; Ashtary-Larky, D. Therapeutic and pharmacological potential of Foeniculum vulgare Mill. A review. J. HerbMed Pharm. 2015, 4, 1-9.

34. Afrisham, R.; Aberomand, M.; Ghaffari, M.; Siahpoosh, A.; Jamalan, M. Inhibitory effect of Heracleum persicum and Ziziphus jujuba on activity of alpha-amylase. J. Bot. 2015, 2015, 824683.

35. Chipiti, T.; Ibrahim, M.A.; Singh, M.; Islam, M.S. In vitro $\alpha$-amylase and $\alpha$-glucosidase inhibitory effects and cytotoxic activity of Albizia antunesiana extracts. Pharmacogn. Mag. 2015, 11, S231-S236. [PubMed]

36. Chilelli, N.C.; Burlina, S.; Lapolla, A. AGEs, rather than hyperglycemia, are responsible for microvascular complications in diabetes: A "glycoxidation-centric" point of view. Nutr. Metab. Cardiovasc. Dis. 2013, 23, 913-919. [CrossRef] [PubMed]

37. Nahar, L.; Nasrin, F.; Zahan, R.; Haque, A.; Haque, E.; Mosaddik, A. Comparative study of antidiabetic activity of Cajanus cajan and Tamarindus indica in alloxan-induced diabetic mice with a reference to in vitro antioxidant activity. Pharmacogn. Res. 2014, 6, 180-187.

38. Ozçelik, B.; Kartal, M.; Orhan, I. Cytotoxicity, antiviral and antimicrobial activities of alkaloids, flavonoids, and phenolic acids. Pharm. Biol. 2011, 49, 396-402. [CrossRef]

39. Liu, X.L.; Zhang, X.J.; Fu, Y.J.; Zu, Y.G.; Wu, N.; Liang, L.; Efferth, T. Cajanol inhibits the growth of Escherichia coli and Staphylococcus aureus by acting on membrane and DNA damage. Plant Med. 2011, 77, 158-163. [CrossRef]

40. Adamczak, A.; Ożarowski, M.; Karpiński, T.M. Antibacterial Activity of Some Flavonoids and Organic Acids Widely Distributed in Plants. J. Clin. Med. 2020, 9, 109. [CrossRef]

Publisher's Note: MDPI stays neutral with regard to jurisdictional claims in published maps and institutional affiliations.

(C) 2020 by the authors. Licensee MDPI, Basel, Switzerland. This article is an open access article distributed under the terms and conditions of the Creative Commons Attribution (CC BY) license (http://creativecommons.org/licenses/by/4.0/). 